J. Clin. Chem. Clin. Biochem.

Vol. 24, 1986, pp. 277-282

(C) 1986 Walter de Gruyter \& Co.

Berlin - New York

\title{
Metabolic Effects of Water Deprivation ${ }^{1}$ )
}

\author{
By M. Hohenegger, U. Laminger, P. Om
}

Institute of General and Experimental Pathology, University of Vienna

\section{A. Sadjak}

Institute of Functional Pathology, University of Graz

K. Gutmann and $M$. Vermes

Institute of General and Experimental Pathology, University of Vienna

(Received February 25, 1985/January 2, 1986)

\section{Summary}

1. Under the conditions of pair feeding, water-deprived rats predominantly use fat as a metabolic fuel, whereas total energy turnover as measured by oxygen consumption is not altered.

2. Plasma free fatty acids are elevated in dehydrated rats, indicating enhanced lipolysis.

3. Reduced hepatic fatty acid synthesis and reduced triacylglycerol secretion into the blood seem to be the main factors for the decrease of plasma triacylglycerol, observed 48 hours after the onset of water deprivation.

4. Enhanced plasma levels of corticosterone (about 100\%) and glucagon (about 50\%) may contribute to the metabolic situation observed in water deprivation.

\section{Stoffwechselwirkungen von Wasserentzug bei Ratten}

\section{Zusammenfassung}

1. Unter der Bedingung der Paarfütterung verwerten Ratten nach Wasserentzug vorwiegend Fett als Stoffwechselsubstrat, wobei der gesamte Energieumsatz der Tiere nicht verändert ist.

2. Die Konzentrationen der freien Fettsäuren im Plasma sind bei dehydrierten Ratten erhöht, was auf eine gesteigerte Lipolyse hinweist.

3. 48 Stunden nach Wasșerentzug ist die Fettsäuresynthese in der Leber als auch die Sekretion von Triacylglycerin in das Blut vermindert. Als Folge ist auch die Konzentration von Triacylglycerin im Plasma herabgesetzt.

4. Erhöhte Konzentrationen von Corticosteron (um 100\%) und Glucagon (um 50\%) im Plasma dürften zu dieser Stoffwechselsituation bei Wassermangel wesentlich beitragen.

1) This work was supported by Ősterreichischer Fonds zur Förderung der wissenschaftlichen Forschung, Projekt 3346.

J. Clin. Chem. Clin. Biochem. / Vol. 24, 1986 / No. 5 


\section{Introduction}

In 1971 Bintz, Bintz \& Riedesel (1) reported low respiratory quotients $(R Q)$ in rats under water deprivation. They concluded that fat catabolism is typical for this state.

Their experiments were performed, however, without control of food intake. We thus decided to repeat these studies under the condition of pair-feeding and to include measurements of several other parameters of lipid metabolism (plasma lipids, fatty acid synthesis, removal of intravenous lipid loads, triacylglycerol secretion into the blood). In this way we expected to obtain a deeper insight into the different pathways of lipid metabolism in the dehydrated animal.

\section{Materials and Methods}

Male Sprague-Dawley rats weighing $250-350 \mathrm{~g}$ were generally employed, but smaller animals $(100-150 \mathrm{~g})$ were used for studying fatty acid synthesis.

Some days before and throughout the metabolic study the animals were housed in individual metabolic cages. Room temperature was $23-25^{\circ} \mathrm{C}$, relative humidity $50-60 \%$. Rats were deprived of water for 24 or 48 hours, the thirsting period beginning at noon. Another group had free access to tap water until the measurements were performed. All rats were fed a standard pellet diet ( $\mathrm{Fa}$. Tagger, Graz) which was offered once or twice a day (at $9 \mathrm{a} . \mathrm{m}$. or at $9 \mathrm{a} . \mathrm{m}$. and $5 \mathrm{p}$. m.). The food consumed by the thirsting rats was measured by weighing and reweighing. On the basis of the measured food intake the control group was pair-fed one day later. Urine volume was measured in most experiments. Several types of experiments with minor changes of this general protocol were performed. These are schematically summarized in table 1 .
1. In the first type of experiment meals were given at 5 p. $m$. and $9 \mathrm{p} . \mathrm{m}$. Oxygen consumption and $R Q$ were measured as reported previously (2) by employing a diaferometer (Kipp and Zonen, Delft) either 24 or 48 hours after the start of water deprivation. After these measurements rectal body temperature was recorded. The rats were then anaesthetized with ether, blood was taken by cardiac puncture and collected in heparinized test tubes. The haematocrit, and in some cases $\mathrm{pH}$ (electrometrically) were measured in whole blood. Glucose (3), osmolarity (Fiske osmometer), urea (4) free fatty acids (5) cholesterol (6), free and total glycerol (7) and phospholipids (8) were determined in heparin plasma.

2. In other groups of rats pretreated as above, triacylglycerol secretion into the blood was measured. In this case the increase of plasma triacylglycerol concentration following an intravenous injection of Triton WR $\left.1339{ }^{\circ}\right)$ ( $6 \mathrm{ml}$ of a $10 \%$ solution in $9 \mathrm{~g} / \mathrm{l}$ sodium chloride per $\mathrm{kg}$ body weight into a tail vein) was determined. Plasma triacylglycerol measurements were performed before, and 30 and 60 minutes after the Triton injection. Immediately after the last determination of triacylglycerol, the plasma volume was measured by the Evans-blue method. In practically all details, we followed the experimental protocol described by Otway \& Robinson (9).

During the first hour after Triton, the plasma triacylglycerol increases linearly as described previously (10). Triacylglycerol secretion was calculated by multiplying the increase of triacylglycerol concentration $(\mu \mathrm{mol} / \mathrm{ml} \cdot \mathrm{h})$ by plasma volume $(\mathrm{ml} / \mathrm{kg}$ body weight).

3. In further experiments the disappearance of an intravenous lipid load was investigated after a period of water deprivation of 48 hours. Pretreatment was the same as described above with the sole exception that in the morning of the third day no meal was offered (see tab. 1). In light ether anaesthesia $33 \mathrm{ml}$ Intralipid $20 \% \otimes$ per $\mathrm{kg}$ body weight was injected into a tail vein at noon. Before injection, as well as 15,17 and 135 minutes later, blood was taken from the cut end of the tail and collected in heparinized test tubes. Total lipids were measured (11) in the plasma.

2) polymeric p-isooctyl-polyethylene-phenol

Tab. 1. Experimental design.

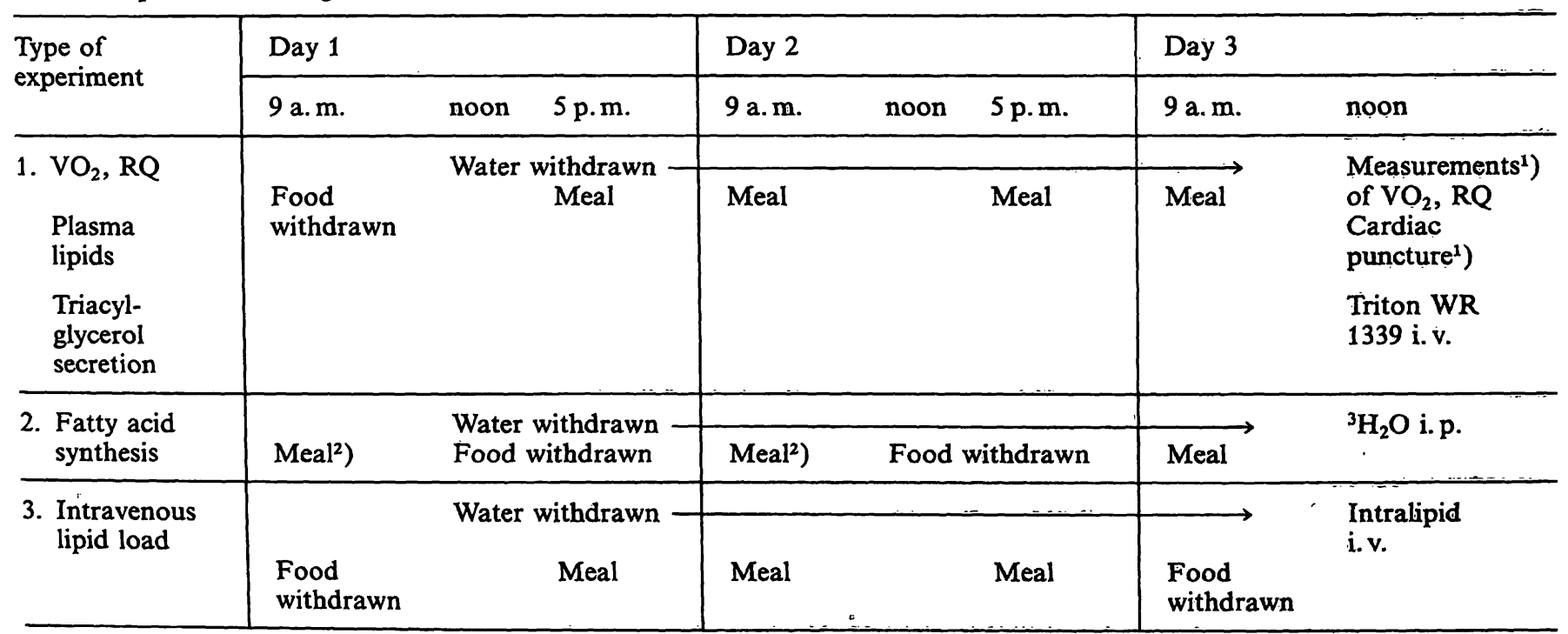

1) In some groups these measurements were performed at noon of the 2 nd day.

${ }^{2}$ ) In this experiment the meals were offered from 9 a.m. till noon only.

The quantities of food consumed were always measured before a new meal was offered. 
4. In a fourth type of experiment lipid synthesis was studied 48 hours after water deprivation. During these experiments only one meal per day was offered from 9 a. m. till noon (see tab. 1). At noon of the third day $370 \mathrm{MBq}$ of ${ }^{3} \mathrm{H}_{2} \mathrm{O}$ in $5 \mathrm{ml}$ of $9 \mathrm{~g} / \mathrm{l}$ sodium chloride solution per $\mathrm{kg}$ body weight was injected intraperitoneally. One hour later the rats were killed by cervical dislocation performed in light ether anaesthesia. The liver was rapidly removed. Total fatty acids were extracted in two aliquots of approximately $300 \mathrm{mg}$. Plasma was obtained by cardiac puncture immediately before the animals were sacrificed. The extraction of fatty acids was performed according to Lowenstein (12) with modifications as described by Gutmann (13). In the extracts and in plasma, radioactivity was determined in a Beckman Liquid Scintillation Counter with toluene PPOPOPOP (1 $1 / 6 \mathrm{~g} / 0.1 \mathrm{~g})$ as scintillation fluid.

This experiment was repeated with the following changes during the pretreatment period: one group of rats received $30 \mathrm{ml}$ of water per $\mathrm{kg}$ body weight by stomach tube twice daily $(9 \mathrm{a} . \mathrm{m}$. and $5 \mathrm{p} . \mathrm{m}$.). Additionally they had unrestricted access to tap water. The other group was deprived of water as above. The rats of both groups were injected intramuscularily which 0.5 I. U. of pitressin tannate ${ }^{\circledR}$ in oil at 9 a.m. and 5 p. m., the last injection being applied at $9 \mathrm{a}$. $\mathrm{m}$. of the third day. Three hours later ${ }^{3} \mathrm{H}_{2} \mathrm{O}$ was injected. Pair-feeding and measurement of lipid synthesis was carried out as described above.

5. In a last type of experiment plasma hormone levels were determined in rats deprived of water for 24 or 48 hours; controls were pair-fed as above.

The following hormones were measured: triiodothyronine and glucagon by radioimmunoassay $(14,15)$, insulin by enzymeimmunoassay (16), corticosterone by fluorometry (17), cortisol by competitive protein binding assay (18), adrenalin, norepinephrine and dopamine according to Da Prada \& Zürcher (19).

For the determination of catecholamines, blood was obtained by puncture of a carotid artery in light ether anaesthesia. For the measurement of other hormones, blood was obtained by cardiac puncture.

\section{Chemicals}

${ }^{3} \mathrm{H}_{2} \mathrm{O}$ was obtained from Amersham International plc., chemicals and enzymes for the determination of glucose, urea, glycerol, cholesterol and insulin were provided by Boehringer, Mannheim. Salts, Evans blue and reagents for the measurements of total lipids, phospholipids and corticosterone were obtained by Merck, Darmstadt; Triton WR 1339 by Serva, Heidelberg; Intralipid® was a gift from KabiVitrum, Wien; Pitressin tannate ${ }^{\circledR}$ a gift from Parke Davis \& Co., Hounslow. Reagents for triiodothyronine and glucagon measurements were obtained from Serono AG, Wien, those for the determination of cortisol and catecholamines from Amersham International plc., Merck, Darmstadt and Sigmä Chemie, München.

\section{Statistics}

Means \pm SD were calculated from all experimental groups and compared by non=paired t-tests.

\section{Results}

The general state of the animals was not essentially altered after a period of $\mathbf{4 8}$ hours of water deprivation. Arterial systolic pressure varied between 80 and $100 \mathrm{~mm} \mathrm{Hg}$ in all groups of normal and water deprived rats. Blood $\mathrm{pH}$ values were not influenced by water withdrawal. The food intake of water-deprived rats (and pair-fed controls) was between 5 and $10 \mathrm{~g}$ pellets per day. This is about half the intake generally consumed by our rats.

Water deprivation over a period of 24 hours induced significant changes ( $p$ at least $<0.05$ ) in only a few parameters. Weight loss was more important than in pair-fed controls $(-5.3 \pm 1.5 \%$ of body weight vs. $-1.5 \pm 0.3, \mathrm{n}=24$ in both groups), osmolality and plasma urea were elevated $(321 \pm 11 \mathrm{mosmol} / \mathrm{kg}$ vs. $303 \pm 10, \mathrm{n}=13$ in both groups; $4.5 \pm 0.8 \mathrm{mmol} / 1$ vs. $6.3 \pm 0.5, \mathrm{n}=9$ in both groups) as well as plasma levels of free fatty acids $(318 \pm 59 \mu \mathrm{mol} / 1$ vs. $253 \pm$ $38, n=9$ in both groups). The urine volume of waterdeprived rats was reduced by about $75 \%$ vs. controls.

Table 2 shows the results obtained 48 hours after the beginning of water withdrawal. There was a further decrease of body weight and a significant increase of the haematocrit; osmolality and plasma urea showed further elevation vs. controls. Mean plasma volume was reduced in dehydrated rats by about $10 \%$; the difference, however, was not significant as a consequence of similar standard deviations $( \pm 10 \%$, see tab. 4). Oxygen consumption was not altered by water deprivation, but $R Q$ values were significantly reduced (tab. 2).

Tab. 2. General observations in rats deprived of water for 48 hours and in pair-fed controls. Means $\pm S D$, number of measurements in ().

\begin{tabular}{|c|c|c|}
\hline & Controls & $\begin{array}{l}\text { Water } \\
\text { deprivation }\end{array}$ \\
\hline $\begin{array}{l}\text { Loss of body weight, } \\
\% \text { of initial weight }\end{array}$ & $\begin{array}{r}-1.6 \pm 0.4 \\
p\end{array}$ & $\begin{array}{l}-9.5 \pm 2.8 \\
(24) \\
0.0001\end{array}$ \\
\hline Haemàtocrit & $\begin{array}{l}0.46 \pm 0.03 \\
(9) \\
p\end{array}$ & $\begin{array}{l}0.49 \pm 0.02 \\
(9) \\
0.05\end{array}$ \\
\hline $\begin{array}{l}\text { Plasma osmolality, } \\
\mathrm{mosmol} / \mathrm{kg}\end{array}$ & $\begin{array}{l}306 \pm 12 \\
(13) \quad p\end{array}$ & $\begin{array}{l}330 \pm 10 \\
(13) \\
0.01\end{array}$ \\
\hline $\begin{array}{l}\text { Urine volume, } \\
\mathrm{ml} / \mathrm{kg} \text { body weight per } 48 \mathrm{~h}\end{array}$ & $\begin{array}{ll}56 \pm 5.4 & \\
(9) & p\end{array}$ & $\begin{array}{l}12 \pm 5.4 \\
(9) \\
0.0001\end{array}$ \\
\hline $\begin{array}{l}\text { Oxygen consumption, } \\
\text { 1/kg body weight per } 24 \mathrm{~h}\end{array}$ & $\begin{array}{l}38.8 \pm 5.0 \\
(24) \\
n .\end{array}$ & $\begin{array}{l}41.7 \pm 7.0 \\
(24)\end{array}$ \\
\hline RQ & $\begin{array}{l}0.86 \pm 0.066 \\
(24) \\
p\end{array}$ & $\begin{array}{l}0.79 \pm 0.047 \\
(24) \\
0.001\end{array}$ \\
\hline
\end{tabular}


The concentrations of some metabolites in plasma are shown in table 3.

Concentrations of cholesterol and phospholipids in plasma did not change even after 48 hours of water deprivation, whereas free fatty acid levels increased

Tab. 3. Concentrations of some plasma metabolites in rats deprived of water for 48 hours and in pair-fed controls. Means $\pm \mathrm{SD}$, number of measurements in ().

\begin{tabular}{|c|c|c|}
\hline & Controls & $\begin{array}{l}\text { Water } \\
\text { deprivation }\end{array}$ \\
\hline Free fatty acids $(\mu \mathrm{mol} / \mathrm{l})$ & $\begin{array}{l}469 \pm 155 \\
(21) \\
p\end{array}$ & $\begin{array}{l}592 \pm 121 \\
(21) \\
0.01\end{array}$ \\
\hline Cholesterol (mmol/l) & $\begin{array}{l}1.53 \pm 0.21 \\
(8) \quad n .\end{array}$ & $\begin{array}{l}1.68 \pm 0.26 \\
(8)\end{array}$ \\
\hline $\begin{array}{c}\text { Phospholipids (mmol/l) } \\
: \vdots\end{array}$ & $\begin{array}{l}1.72 \pm 0.22 \\
(8) \quad n .\end{array}$ & $\begin{array}{l}1.83 \pm 0.38 \\
(8)\end{array}$ \\
\hline Glucose (mmol/l) & $\begin{array}{l}4.00 \pm 0.50 \\
(12)\end{array}$ & $\begin{array}{l}4.61 \pm 0.61 \\
(12) \\
0.05\end{array}$ \\
\hline Urea (mmol/l) & $\begin{array}{l}4.5 \pm 0.8 \\
(12)\end{array}$ & $\begin{array}{l}8.5 \pm 0.7 \\
(12) \\
0.001\end{array}$ \\
\hline
\end{tabular}

further during the 24 to 48 hours after the beginning of the experiment. There was also an increase of free fatty acids in controls, as this group was pair-fed with the water deprived rats.

Triacylglycerol secretion into the blood as well as hepatic fatty acid synthesis and plasma triacylglycerol levels were diminished under water deprivation (tab. 4 and 5). An additional experiment (tab. 5) showed that high doses of vasopressin given to water-loaded or water-deprived rats had no effect on fatty acid synthesis when compared with corresponding animals receiving no vasopressin.

The ability to remove an intravenous lipid load (intralipid test) was not different in dehydrated and control rats. Before Intralipid, total lipid plasma levels were about $3000 \mathrm{mg} / \mathrm{l}, 15$ minutes later about $10000 \mathrm{mg} / \mathrm{l}$ in both groups. Two hours later a decrease to the values before the lipid load was observed in all rats. After twenty four hours of water deprivation there was no alteration of plasma hormone levels. After 48 hours the plasma levels of triiodothyronine were significantly decreased, while those of glucagon and corticosterone were significantly elevated in waterdeprived rats. On the other hand plasma levels of insulin, cortisol, adrenaline, norepinephrine and dopamine remained unaltered (table 6).

Tab. 4. Plasma triacylglycerol and triacylglycerol secretion in rats deprived of water for 48 hours and in pair-fed controls. Means $\pm \mathrm{SD}$, number of experiments in ().

\begin{tabular}{lrrrr}
\hline & Controls & Water deprivatiốn & Significance \\
\hline Plasma triacylglycerol before Triton, $\left.\mu \mathrm{mol} / 1^{*}\right)$ & $855 \pm 247$ & $(7)$ & $505 \pm 87(7)$ & $\mathrm{p}<0.01$ \\
Increase of plasma triacylglycerol, $\left.\Delta \mu \mathrm{mol} / \mathrm{l}^{* *}\right)$ & $2958 \pm 663(6)$ & $2178 \pm 663(6)$ & $\mathrm{p}<0.05$ \\
Plasma volume, $\mathrm{ml} / \mathrm{kg}$ body weight & $41 \pm 2.1(6)$ & $37.2 \pm 4(6)$ & $\mathrm{n} . \mathrm{s}$. \\
Triacylglycerol secretion, $\mu \mathrm{mol} / \mathrm{h} \cdot \mathrm{kg}$ body weight & $121 \pm 2.5(6)$ & $81 \pm 28(6)$ & $\mathrm{p}<0.05$ \\
\hline
\end{tabular}

*) Plasma total glycerol minus plasma free glycerol.

**) During 1 hour following Triton injection.

Tab. 5. Fatty acid synthesis by the liver in rats deprived of water for 48 hours and in pair-fed controls: Means \pm SD, number of experiments in ().

\begin{tabular}{lcl}
\hline Experimental group & $\begin{array}{l}\text { Urine volume ml/48 } \mathbf{~} \\
\text { per } \mathrm{kg} \text { body weight }\end{array}$ & $\begin{array}{l}\text { Fatty acid synthesis, } \\
\mu \text { mol }{ }^{3} \mathrm{H}_{2} \mathrm{O} \text { incorporated into fatty } \\
\text { acids of } 1 \text { g liver dry weight }\end{array}$ \\
\hline $\begin{array}{l}\text { Controls (water ad libitum) } \\
\text { Water deprivation }\end{array}$ & $110 \pm 28(8)$ & $85 \pm 31(8)$ \\
Signficance & $24 \pm 4(8)$ & $31 \pm 12(8)$ \\
$\begin{array}{l}\text { Controls (water ad libitum } \\
+ \text { water per stomach tube } \\
+ \text { vasopressin)* }\end{array}$ & $\mathrm{p}<0.0001$ & $78 \pm 26(10)$ \\
$\begin{array}{l}\text { Water deprivation } \\
+ \text { vasopressin*) } \\
\text { Significance }\end{array}$ & $43 \pm 18(10)$ & $26 \pm 11(10)$ \\
\hline
\end{tabular}

*) For details see methods. 
Tab. 6. Plasma levels of different hormones in rats deprived of water for 48 hours an in pair-fed controls: Mean \pm SD, number of measurements in duplicate in ().

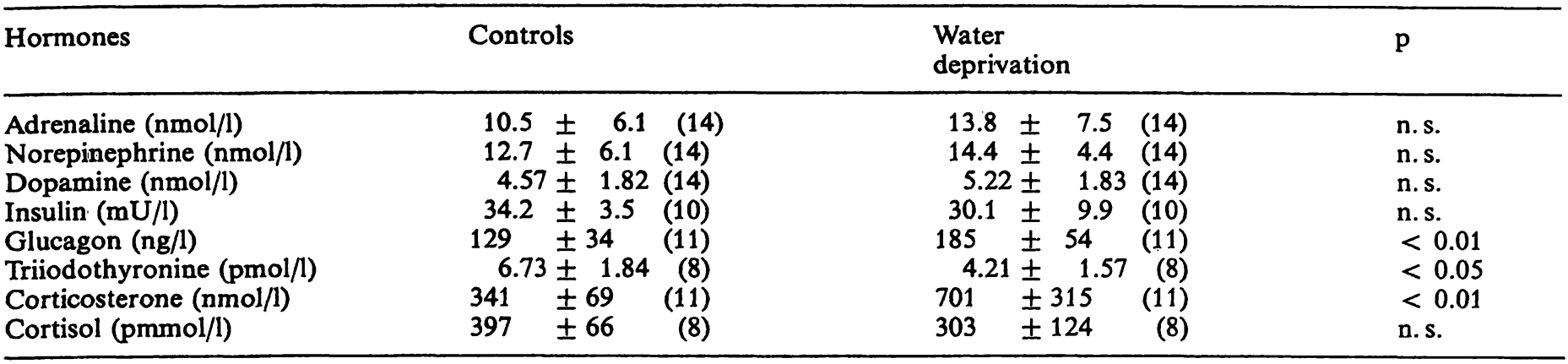

\section{Discussion}

\section{General}

Water deprivation over a period of 48 hours results in an increase of plasma osmolality and haematocrit and a decrease of plasma volume, all in the range of $\pm 10 \%$. Thus, increases of about $10 \%$ in the levels of any substance in plasma may be seen as the simple consequence of reduced plasma volume. On the other hand, lowered plasma levels may be underestimated to the same extent. This may apply in the case of reduced plasma triacylglycerol and triiodothyronine. Increased glucose in plasma may in part be due to reduced plasma water, although an additional glucagon effect cannot be ruled out. In contrast, the increases of corticosterone and glucagon in plasma (about 100 and $50 \%$, respectively) cannot be explained in this way. The data for triacylglycerol secretion, fatty acid synthesis and removal rate of an intravenous lipid load are not influenced by reduced plasma volume, because this phenomenon is already included in the calculations.

\section{Pathogenetic mechanisms}

Relations between water balance and lipid metabolism have scarcely been investigated and such studies have been restricted to only a few parameters $(1,20$, 21,22 ). The primary aim of this study was, therefore, to give a description of different aspects of lipid metabolism by including dynamic tests and determination of several plasma levels of hormones involved in lipid metabolism.

A synopsis of all metabolic data leads to the following conclusions: In water-deprived rats lipids are predominantly used as a metabolic fuel at a normal energy turnover (normal oxygen consumption, low RQ, increased plasma free fatty acids). Hepatic fatty acid synthesis and secretion of triacylglycerol into the blood are both decreased, whereas lipid transport from the blood to the tissues (Intralipid test) occurs at a normal rate; consequently plasma triacylglycerol decreases.

For the data presented two explanations seem to be possible:

a) Water deprivation causes mainly intracellular dehydration. As a consequence, concentrations of electrolytes and other substances within the cell may be altered. Changes of the intracellular environment may affect the activity of enzymes involved in metabolic regulation. Exact data on this subject, however, is lacking and such considerations remain speculative at the moment.

b) According to Hems et al. (23) vasopressin reduces fatty acid synthesis of isolated perfused mouse liver. From our study it cannot be concluded that vasopressin might be involved in diminished fatty acid synthesis (tab. 5). The plasma levels of glucagon and corticosterone, however, were elevated in our waterdeprived rats, which might account for the alterations of lipid metabolism. It is known that glucagon enhances lipolysis and decreases fatty acid synthesis; corticosterone also increases lipolysis as the main adrenocortical hormone of the rat; its effect on fatty acid synthesis is not known $(24,25)$. Glucagon enhances formation of ketone compounds (26); in our study these were not measured in the plasma. In the urine no elevated ketone excretion was demonstrated and blood $\mathrm{pH}$ was unaltered. Triiodothyronine increases both lipolysis and fatty acid synthesis (27). Decreased plasma levels of this.hormone cannot, therefore, explain the pattern of lipid metabolism observed; furthermore energy turnover remained normal in dehydrated rats. Plasma levels of free thyroid hormones, however, should be known in order to evaluate the role of the thyroid gland in water deprivation.

In addition to plasma hormone levels, altered effects of the hormones on target cells have to be considered. Experimental data on this subject under the conditions of water deprivation are totally lacking at the moment. 


\section{References}

1. Bintz, G. L., Bintz, L. B. \& Riedesel, M. L. (1971) Comp. Biochem. Physiol. 38A, 121-127.

2. Hohenegger, M., Marktl, W. \& Rudas, B. (1974) Pflüger's Archiv Europ. J. Physiol. 351, 331 - 338.

3. Schmidt, F. H. (1961) Klin. Wochenschr. 39, 1244-1247.

4. Fawcett, J. K. \& Scott, J. A. (1960) J. Clin. Pathol. 13, $156-159$.

5. Dole, V. P. \& Meinertz, H. H. (1960) J. Biol. Chem. 235 , 2595-2599.

6. Röschlau, P., Bernt, E. \& Gruber, W. (1974) Z. Klin. Chem. Klin. Biochem. 12, 403-407.

7. Eggstein, M. \& Kreutz, F. H. (1966) Klin. Wochenschr. 44, $262-267$.

8. Zilversmit, D. B. \& Davis, A. K. (1950) J. Lab. Clin. Med. $35,155-160$.

9. Otway, S. \& Robinson, D. S. (1967) J. Physiol. 190, $321-332$

10. Hohenegger, M. \& Schuh, H. (1984) Exper. Pathol. 25, 89-95.

11. Zöllner, N. \& Kirsch, K. (1962) Z. Ges. Exper. Med. 135, $545-561$.

12. Lowenstein, J. M. (1971) J. Biol. Chem. 246, 629-632.

13. Gutmann, K. (1983) Fettsäuresynthese der Rattenleber in Abhängigkeit von Fütterungsart, Umgebungstemperatur und Zufuhr von Schwermetallen. Thesis, Univ. of Vienna, Austria, 1983.
14. Hesch, R. D., von zur Mühlen, A. \& Hüfner, M. (1975) Methoden der Hormonbestimmung. In: (Breuer, H., Hamel, D. \& Krüskemper, H. L., eds.) Thieme Stuttgart, pp. $127-131$.

15. Henquin, J. C., Malvaux, P. \&, Lambert, A. E. (1974) Diabetologia $10,61-68$.

16. Morren, E. G. (1978) Tijdschr. Belg̀. Verein. Laboratoriumtechnologen 5, 199-219.

17. Zenker, N. \& Bernstein, D. E. (1958) J. Biol. Chem. 231, 695-701.

18. Leclercq, R. G., Copinschki, G. \& Franckson, J. R. M. (1969) Rev. Franç. Etud. Clin. Biol. 14, 815 $=819$.

19. Da Prada, M. \& Zürcher, G. (1976) Life Sci. 19, $1161-1174$

20. Yano, S., Kotani, S., Miyatake, A. \& Yamamura, Y. (1973) Endocrinol. Japon. 20, 345-348.

21. Gerich, J., Penhos, J. C., Gutman, R. A. \& Recant, L. (1973) Diabetes 22, 264-271.

22. Drori, D. (1976) Brit. J. Nutr. 35, 195-200.

23. Hems, D. A. \& Ma, G. Y. (1976) Biochem. J. 160, 23-28.

24. Wakil, S. J., Stoops, J. K. \& Joshi, V. C. (1983) Ann. Rev. Biochem. 79, 537-579.

25. Beynen, A. C., Vaartjes, W. J. \& Geelen, J. J. H. (1979) Diabetes 28, 828-835.

26. Mc Garry, J. D. \& Foster, D. W. (1977) Arch. Int. Med. 137, 495-501.

27. Diamant, A., Gorin, E. \& Shafir, E. (1972) Eur. J. Biochem. $26,553-559$.

Prof. Dr. M. Hohenegger

Institut für allgemeine

und experimentelle Pathologie

der Universität Wien

Währinger Str. 13

A-1090 Wien 